Artículo

\title{
Modernity, Nationalism, and the "Promise of Omnipotence". A Conversation with Hartmut Rosa
}

\author{
Modernidad, Nacionalismo y "promesa de omnipotencia”. Una conversación con \\ Hartmut Rosa
}

\begin{abstract}
Modernidade, nacionalismo e "promessa de onipotência". Uma conversa com Hartmut Rosa
\end{abstract}

Hartmut Rosa *

* FRIEDRICH SCHILLER UNIVERSITÄT JENA

Darío Montero **

** UNIVERSIDAD DE CHILE

\begin{abstract}
:
The interview focuses on Hartmut Rosa's interpretation of the modern nation state. According to his theory, the territorial state, which unifies and standardizes time, language, law and currency, is understood in close dependence with modern processes of social acceleration. A dialectical relationship would take place: while the Westphalian state explains social acceleration, it is also recognized that the nation state became such a successful institution precisely due to the fact that it could accelerate. In the long run, the centrifugal forces of acceleration, which help to bring about contemporary globalization, tend to leave the sovereign state in a fragile condition. On the other hand, the nation, as a separable phenomenon irreducible to the state, seems to be a much less discussed category in Rosa's work. In this interview, Rosa introduces the nation as a cultural engine that provides the motivational force for the state to function properly. His sociological distinction between "cultural" and "institutional" levels is applied to the nation state,
\end{abstract}


necessarily a hybrid. Looking at today's world, Rosa discusses the current rise of national populism and what he calls the "promise of omnipotence" (the idea that the people is all powerful), as a way of explaining the return of nationalism; but he also grapples with the phenomenon of cosmopolitanism (as distinct from globalization) and the hegemony of China.

Keywords: Modernity; Nationalism; Cosmopolitanism; Globalization; Acceleration.

\section{Resumen:}

La entrevista se centra en la interpretación de Hartmut Rosa del Estado nación moderno. Según su teoría, el Estado territorial, que unifica y estandariza el tiempo, el lenguaje, la ley y la moneda, es conceptualizado en íntima vinculación con los procesos modernos de aceleración social. Se produciría aquí una relación dialéctica: si bien es cierto que el Estado Westfaliano explica la aceleración social, también hay que considerar que aquel se convirtió en una exitosa institución precisamente por el hecho de que se podía acelerar. A largo plazo, las fuerzas centrífugas de la aceleración que ayudan a provocar la globalización contemporánea tienden a dejar al Estado soberano en una condición frágil. Por otro lado, la nación, como fenómeno separable y no reducible al Estado, parece ser una categoría mucho menos discutida en la obra de Rosa. En esta entrevista Rosa presenta a la nación como un motor cultural que proporciona la fuerza motivadora para que el Estado funcione correctamente. Su distinción sociológica entre los niveles "cultural" e "institucional" se aplica al Estado nación, necesariamente un híbrido. Observando el mundo de hoy, Rosa analiza el auge actual del populismo nacionalista y lo que él llama la "promesa de la omnipotencia" (la idea de que el pueblo es todopoderoso) como una forma de explicar el regreso del nacionalismo; pero también discute el fenómeno del cosmopolitismo (diferenciándolo de la globalización) y la hegemonía de China.

Palabras clave: Modernidad; Nacionalismo; Cosmopolitismo; Globalización; Aceleración.

\section{Resumo:}

A entrevista centra-se na interpretação de Harmut Rosa acerca do Estado-nação moderno.

Em sua teoria, o Estado territorial, que unifica e padroniza o tempo, a linguagem, a lei e a moeda, é conceitualizado em íntimo nexo com os processos modernos de 
aceleração social. Produz-se, assim, uma relação dialética: embora seja certo que o Estado westfaliano explica a aceleração social, também há de ser levado em consideração que ele se converteu em uma instituição de sucesso precisamente pelo fato de que permitia acelerar. No longo prazo, as forças centrífugas da aceleração que favorecem a globalização contemporânea, tendem a fragilizar a condição do Estado soberano. Por outro lado, a nação, como fenômeno distinto e irredutível ao Estado, parece ser uma categoria menos discutida na obra de Rosa. Entretanto, nesta entrevista o autor apresenta a nação como um motor cultural que promove a força mobilizadora para que o Estado funcione corretamente. Sua distinção sociológica entre os níveis "cultural" e "institucional" é aplicada ao Estado-nação que é necessariamente um híbrido. Observando o mundo de hoje, Rosa discute a emergência atual do populismo com viés nacionalistas e o que ele chama de "promessa de onipotência" (a ideia de que o povo é todo- poderoso) uma outra forma de explicar a volta do nacionalismo. Além disso, Rosa trata do fenômeno do cosmopolitismo (distinguindo-o da globalização) e da influência da China.

Palavras-chave: Modernidade; Nacionalismo; Cosmopolitismo; Globalização; Aceleração.

Recibido: 20 de septiembre de 2020

Aceptado: 5 de noviembre de 2020 
Dario Montero (DM): Let me start by sharing some of my intuitions with you. I have been writing in the past years a book about the formation of modern society, and one of its chapters deals with the origins and development of the nation state. It seems to me that one of the distinctive features of modern society is nationalism. The Christian Middle Ages was an international society whose center was the Roman papacy; however, from the 15th century onwards, the first modern nations such as England or France began to emerge in Western Europe. Would you agree with the thesis that nationalism is a modern phenomenon and that it is already in the making since early modernity?

Hartmut Rosa (HR): Normally, people refer to the Westphalian Peace, in 1648, as the birth of the modern national state, but I think its development may have started before that period. Distinctions between "us" and "them" are older, maybe universal - ethnic distinctions, for example - are certainly older. I would say that the idea of a nation, which is much vaster and diverse, took off in the 17th century, in early modernity. The nation - I would add - is not blood-based, and it's territorially defined, a closed space which is "yours".

DM: Before we go on, how do you define "early modernity"?

HR: It is the period when the (modern) system starts, roughly speaking during the 17th and 18th centuries; then follows "classical modernity", let's say, until 1989. It must be clear, though, that I do not define these periods chronologically but in a logic of speed. The claim is that early modernity, or pre-modernity, made social change slower than three generations: the "world" of the grandmother is assumed to be the same as her grandchild's. Classical modernity, in turn, is defined by a generational pace of change: each generation is the bearer of innovation, each one must create a new world - a new job, family, place of residence, religious positioning -, but once you become a baker you stay a baker for the rest of your life. Finally, in "late modernity" both the grandmother and the grandchild would agree that right now things are different than ten years ago. My definition of modernity is now what I have called "dynamic stabilization" - a society can be called "modern" when it can only maintain its institutional status quo through innovation, acceleration and growth. I 
would insist that this institutional structure only comes to the full in the 18th century, but of course it does not fall from the blue sky; there are historical developments which lead to it.

DM: Does it seem to you that the phenomenon of nationalism can be distinguished from the process of monopolization of the political, legal, fiscal, and military structures that make up the modern state? If so, I think that you have put much more effort in theorizing the state than the nation. Would you agree?

HR: I must agree that this is not really the forte of my analysis, on these things I did not pay much attention. But what you say now seems quite right to me. What I am writing now might be interesting for what you describe. ${ }^{1}$ Normally, in sociology you have this distinction between structure and action, but I would rather distinguish between structure and culture. And I would say that the state is a question of the institutional structure, while the nation is a kind of cultural concept. The way I want to do the distinction is by saying that institutions need cultural energy, they need to be filled up with energy that comes with desire and anxiety - in fact the nation has become the focus of desire and anxiety, and of course of identification. It is not the state that creates identification, emotional attachment, and emotional energy. This comes through the idea of the nation and not through institutions like the state. Therefore, analytically, you can certainly separate these two concepts, and thus the question is how they develop in proximity.

DM: That is precisely what I'm trying to figure out in the book I'm writing. The nation is a type of bonding, a shared feeling, but then you also see these processes of monopolization at work.

1 Rosa is referring to a series of essays which he is currently writing in dialogue with the German sociologist Andreas Reckwitz. In them, the former offers a sketch of a systematic theory of modern society, particularly his latest attempt at formulating the contours of the "social formation" of modernity. Later in this conversation, Rosa will explicitly refer to this work in progress. Today unpublished, these essays are expected by October 2021, under the title Spätmoderne in der Krise. Was leistet die Gesellschaftstheorie?, by Suhrkamp. 
HR: You might remember that, in the acceleration book, ${ }^{2} \mathrm{I}$ am of the persuasion that what the territorial state does both lies in the logic and works at the service of acceleration. It is a large process of unification and standardization, not just of the fiscal system. It is one currency, one language, one legal system, and this does away with hindrances for circulation of capital and goods, allowing free economic, technological, and communication flows. Standardization makes things calculable, available, attainable, and accessible...

DM: ... of course, in your book on acceleration you speak of these processes of monopolization and standardization of time, language, and law as factors that partly explain the social acceleration of modern societies, for example, scientific-technical acceleration and economic-industrial acceleration.

HR: Yes, but I would almost put it the other way around, I mean, there is probably a kind of dialectical relationship. You said that the state explains acceleration; true, but you could also put it otherwise - the nation state became such a successful concept since it could accelerate. I mean, the logic of acceleration is driving social development at least from early modernity on. So, it was the need for speed, so to speak, which made the state a good idea, a good solution. But you are right. I also say that the state is maybe the central actor. If one asks, how did the logic of dynamic stabilization and social acceleration come into the world? I would say that the state played a huge role. Because of competition between nation states, it was very important to be fast, militarily and in other ways - thereby, the state builds infrastructure, the state has an interest in a strong economy, in technological development, and so on.

DM: But it looks as if the theory of acceleration leaves unexplored the question of the origins of these properly modern phenomena and, more specifically, that the theory takes the bureaucratic state as an independent variable, as an accelerating factor, but one that cannot be explained - at least, not to the same degree - by social acceleration.

2 Hartmut Rosa, Social Acceleration. A New Theory of Modernity (New York: Columbia University Press, 2013). 
HR: The argument tends to become circular there. I would have to rethink this. In any case, in the book there are several things that come together and help explain these phenomena. One is secularization - in a certain interpretation, my "cultural motor": speed becomes an answer to the problem of finitude. Some scholars trace this back to the plague in the 14th century, so not just to the 17 th century, the century of natural science, but much further back. $^{3}$ A second factor is capitalism - in a capitalist system, time becomes a scarce commodity, so there is a need for speed. And the third factor is competition between territorial states, whereby speed also becomes a necessity. However, it is also the shift from an estate-based system to functional differentiation, since once you have a system based on the division of labor, speed becomes an answer to the problem of increasing differentiation. There are several factors which promote, prioritize, and reward speed. If we take all of this into consideration, then the monopolization processes we were discussing - one currency, one language, one time zone, etcetera - are policies which allow speeding up; and so, the state is really an answer to a speed problem created elsewhere.

DM: But I think we agree that the nation is a separable phenomenon, not reducible to the state, which is much less explained by this theoretical framework.

HR: You are right, and I have not written much about the nation. Probably the most I have written about the nation was in my dissertation thesis on Charles Taylor. ${ }^{4}$ Because the nation has to do with identity. What is very interesting to consider is that human beings need to have a sense of their place in the world: where do I fit in, where do I belong. In a system of dynamic stabilization, this question cannot be answered by your social position. You are a peasant or a worker, but you were not born this way and you might end up your life in a different profession. So, the answer to the question of "who am I" needs to be different. And here, probably, the nation comes in and replaces older identities. In the sense of resonance theory, I call it "vertical resonance", a kind of existential resonance: as a

3 Hans Blumenberg, Lebenszeit und Weltzeit (Frankfurt am Main: Suhrkamp, 2001); Marianne Gronemeyer, Das Leben als Letzte Gelegenheit. Sicherheitsbedürfnisse und Zeitknappheit (Darmstadt: Wissenschaftliche Buchgesellschaft, 1993).

4 Hartmut Rosa, Identität und kulturelle Praxis: Politische Philosophie nach Charles Taylor (Frankfurt am Main: Campus, 1998). 
human being, I need to have a sense of where do I fit within the whole, being asked how do you define the whole - and one answer is the nation. ${ }^{5}$

DM: Let me put that on hold and advance to classical modernity. One can say that, from the end of the 19th century on, a world economy has actually overcome the boundaries of national economies; science and technology have successfully spread throughout the world and made possible a revolution in communications and transportation; and that there is a growing cosmopolitan mentality, expressed in philanthropic, medical, artistic, and educational initiatives across national barriers. Is not the theory of social acceleration more adequate for explaining these globalizing phenomena than, for example, the constitution of national welfare states at the beginning of the 20th century?

HR: My standard narration is a two-step process: first the nation state did away with all the obstacles and barriers to the speed of flows within itself, and then globalization kicks in. My claim is almost physical - when you speed up a certain system, the power of the centrifugal forces blows up the borders. This is how I explain globalization: you cannot keep the speed within the frames of the nation state because it tends to explode and expand. And you suggest that, under that logic, we have reached a point by 1900 where we should have developed global systems, but we did not, we developed national states. That is what you meant?

DM: Well, I would say that already by 1900 one can easily see these two movements in modernity: globalization and nationalization $-a$ universalistic and a particularistic tendency.

HR: We just had this conversation with Stephan Lessenich, who referred to citizenship as a clear instrument of closure, of tipping people out - that is a matter of fact. I think the reason for this is that the welfare system somehow depends on a sense of solidarity and of mutual obligation, of mutual interconnectedness, and for this you need the cultural base that was the nation. The welfare state is a re-distributional system, and then of course it requires a 5 Hartmut Rosa, Resonance: A Sociology of Our Relationship to the World (Cambridge: Polity Press, 2019). 
minimal sense of being together, and this is based on a cultural engine which is the nation (and not the state), so this would explain why the welfare system has developed on a national and not on a global level. The motivational force comes from the nation.

DM: Now, when you write on globalization, you refer to changes within late modernity the political revolution that implied the collapse of actual socialism; the digital revolution that brought internet and satellite television; and the economic revolution of flexible accumulation and "turbocapitalism". All three are accelerating movements, all three can also be understood as forms of globalization. These changes imply the crisis of the national state in which it has become an obstacle to acceleration, and this crisis is resolved via a change in orientation towards deregulation - what we know as neoliberalism. Am I getting this right?

HR: Yes, in my view "neoliberalism" really is the latest acceleration project at every level. What I am working on right now is that you need an explanation about where the energy comes from, you need to adopt sooner or later, in the sociological analysis, this cultural standpoint. A system cannot grow or accelerate in and for itself, you need motivational energies, and neoliberalism releases some forms of motivational energy by creating existential anxiety for all workers: everyone should always fear that she might lose her legitimate basis in the society or the world. A crisis of the national state persists because now there are new types of ruptures or gaps emerging within nation states - for example, this distinction between the "somewheres" and the "anywheres", which I find quite interesting. ${ }^{6}$ Right now, it is kind of obvious that there is solidarity and a feeling of being together among the "anywheres". Think of what we are doing right now: the academic elites somehow are much closer than, say, the workers at the national level. So, the nation seems to be no longer capable of creating this energy, then it creates a kind of backlash by the new forces of national populism...

6 This distinction got popularized in the UK by journalists and public intellectuals during the past few years. Those who see the world from "anywhere" usually belong to the educated elites and have so-called portable identities, which makes them feel at home in new places and among new people - as opposed to those more strongly rooted in local identities, who feel uncomfortable with the rapid changes of the modern world. 
DM: ... which is a more recent phenomenon. Because you published your book on acceleration in 2005, when globalizing neoliberalism was not really under threat, you did not have the chance to observe the nationalist and populist rise of the second decade of the 21 st century, the current animosity between "nationalists" and "globalists", or at least the skepticism of the former versus the latter that, for example, portraits contemptuously Obama and Biden as globalists...

HR: Actually, the leaders of Alternative für Deutschland (AfD) - our rising right populist party in Germany -, Alice Weidel and Alexander Gauland, finally congratulated Joe Biden on his win, ${ }^{7}$ but there are texts from party leaders saying one should not congratulate a neoliberal globalist...

DM: So, this only confirms that these are real forces operating in current politics. How can we come to terms with the rise of national populism? Is it a mere reaction to this globalizing neoliberalism, as you just implied?

HR: If you think along the lines we just drew - making this distinction between the institutional and the cultural levels -, then the state became somehow old-fashioned in the global system, particularly facing the economic and financial systems. The European Union shows the typical trend of the last decades, in the sense of an overcoming of the boundaries of territorial states. However, at the cultural level, nothing has yet replaced the nation as the thing that helps you identify, define your place in the world, your sense of belonging and being together. Therefore, at the cultural level the nation is still a focal point, but on the institutional level there was a transformation towards globalization, and this misfit is now kind of apparent - people want the nation back.

DM: So, could we say that the current crisis of the national state is more a crisis of the state than of the nation...?

7 This interview was conducted in late November 2020, several weeks after the US Presidential election that is being mentioned. 
HR: Yes, unfortunately, I have to say. It is not that I like it, but it seems that people's identification with their nations has actually grown during the last couple of decades.

DM: As you have suggested in your book, accelerating globalization has produced two things: state deregulation, on the one hand, that has allowed savage globalism and an impact on collective identities in the sense of their dynamization, liquidation, even dissolution, on the other. Can these factors explain the revaluation of national identities with chauvinist overtones, as embodied by Brexit, Trump, and Bolsonaro?

HR: It just comes to my mind that I have a perfect explanation for this. It is an idea that came to my mind very recently, so I told myself "why didn't I think of it before?". Brexit and Donald Trump are the most clear-cut cases, but you also find it with current India president Narendra Damodardas Modi, Jair Bolsonaro, and others. What happens now seems to me to be crystal-clear. The idea of popular sovereignty inherent to democracy the power should stand with the people - is the promise of modernity, namely, that it's not the Church or the king who tells me how to live - on the contrary, "we, the people" are who shape our own form of living. Such is a very clear and powerful promise. And roughly this is my new theory: the problem is this promise of omnipotence - not only in the political realm, but in general. If the power stands with the people, therefore "no one can stop us". I call this the promise of omnipotence in which the demos can do anything. But experience reveals that you can do nothing against the logic of the financial markets, against global inequalities, against speed. The people who voted for Brexit or for Trump manifested a total frustration, they really saw themselves as victims: "our voices are not heard, we cannot do anything against these logics". And here it comes in right-wing populism. The Brexit slogan was "Take back control", while Trump said something like "I don't give a damn about international laws and treaties and regulations, I just impose new tariffs"; "I don't give a damn about what's possible or not, what are the legal obligations, I will just do it". This is really going back to the promise of popular sovereignty, which is not just an abstract scheme, but the idea that we the people can have political power. And since it is very unclear how political power could be exerted at the global level, people tend to like 
figures like Boris Johnson and Trump who, at the national level, are able to make a credible claim: "We have the power in our hands".

DM: And I would say that such is a promise more intimately connected with the nation than with the state...

HR: Again, it is the fit between the two. The nation is the cultural promise, but the instruments through which this could become a credible promise are state institutions (parliament, government, and so on).

DM: Yes, but I think that the new element really comes along with the nation. Take France as an example. The French, centralized state was already in place under Louis XIV, the absolute king, the same state which later took over Robespierre, then Napoleon, then the Third Republic, and so on. This legal and administrative structure was in place before the Revolution. What changed was a shift in the legitimacy principle - from the king to the people. That is why I think that the promise of democracy you are referring to is tied, strictly speaking, to the nation and not to the state.

HR: I think I totally agree with you. The promise of popular sovereignty is the power of the nation through the instruments of the state, which in the case of France were in place beforehand; but the history of Germany is the other way around, as the nation was an idea that was in place before the state actually came into being.

DM: You are right, and very much based on language, literature, and culture in general. My point would be that, despite the chronological order in which it appears, the nation, culturally understood, is the modern motivating force.

HR: And that does not change but rather reinforces the basic theory we are discussing here: in both cases you can identify a cultural element and an institutional element. 
DM: Now, what about nationalist separatism after the fall of the Berlin Wall, and the affirmation of indigenismo in Latin America and other regions of the world? Can they be understood in part as reactions to a flattening globalization?

HR: It might interest you the idea of "repulsive globalization" which has been recently developed by Klaus Dörre. His idea is that globalization has a negative effect on itself, so it produces backlashes. For me, the nation is no longer the obvious and only focal point of identification for all segments of the population alike. Take again the academic elites as an example: we feel much closer to each other in Santiago, Jena and elsewhere than I feel to the AfD people, or that you might feel to the Pinochet followers in Chile. Tension is created out of the fact that the logic of institutions - state bureaucracy - points in the direction of globalization, while cultural aspirations do not want to overcome the nation at all. People are looking for a more convincing form of cultural coherence or solidarity, and thus Catalans, for example, have discovered that they have much more in common among them than with respect to the rest of the Spanish people.

DM: So, following our sociological distinction, we may say that globalization has to do with this structural explanation, and cosmopolitanism with the cultural aspect.

HR: I totally agree.

DM: I imagine cosmopolitanism like a conversation across cultures or nations. First, you need differentiation between national cultures so that then anyone can travel, learn languages, study and live abroad. Young people are nowadays very prone to these crosscultural adventures.

HR: Yes, but my question is, why does cosmopolitanism not develop stronger and overcome national references?

DM: I think that part of the answer is because cosmopolitanism, well understood, needs nations, or at least a myriad of qualitatively different cultures. If you eliminate this base, 
then you get this sort of flat globalization which so many people hate. Instead, people want to engage in a conversation with others, you need to hear other voices, different to your own. And this might bring us back to your theory of resonance...

HR: Exactly, I was just thinking the same.

DM: One of the valid criticisms behind this wave of national populism is that you do not really hear other voices within our abstract and bureaucratic international system, the system, say, set up by Wilson after the First Word War, the 14 points he imposed on Europe, the establishment of the League of Nations, the prominent role played since then by the US, etcetera. Turning now to the last part of your intellectual work, one can understand the nation as a "space of resonance", as a sense of belonging, that raises strong feelings, thanks to which and within which a public sphere and democratic polity can thrive - but also a soccer league, a national team, a literature, a culinary tradition, ways of life. How does your theory of resonance approach the phenomenon of nationalism?

HR: As I said, nationalism is not a strong focal point of my analysis. But I totally agree with the line of thought you were just developing. Resonance always occurs between two or more entities. You need a space of resonance for listening and answering. You are clearly right that, culturally as well as legally and politically speaking, modernity creates the nation state as a sphere of resonance where people could listen and answer among each other. The media, the great newspapers - for example, the New York Times or the Frankfurter Allgemeine - provide a national public space for listening and answering: you read different papers, and even within each paper you might hear different voices. It is the same with national culture, with national literature, and it has a lot to do with language: the basic operation of resonance is listening and answering. At the minimum, this requires that I have a voice and that I have ears, that I am capable of understanding what you have to say, but one also needs a place to meet, so the public sphere is of utmost importance. It was the nation which created and provided this open sphere for the exchange of ideas and opinions. In turn, this relates to the reality created by a single language, educational system, media network, etcetera. Politics also occurs mainly at the national level. 
DM: Although your argument sounds clear and plausible, it still remains partially unanswered the question of origins: why nations historically emerged in the first place?

HR: I really think of it in terms of dynamization. There was long-term travelling even before the railway came along. But once you have the railway, it creates movement within a larger physical space; and, as you said, there appears the standardization of time, of the postal system, of the fiscal system. It would have been so difficult if every village had a different fiscal system, currency, or law. So, if you want to speed up social interaction, you must standardize and coordinate actions, and this demands a certain size. Before modernity, territorial units were smaller and more unstable.

DM: You have mentioned that supranational organizations like the European Union are being perceived by many Europeans as distant, cold bureaucratic spaces. In contrast, nationalism - even in its worst forms - continues to have an appeal on people, it is still a source of social belonging and meaning. This is one of the reasons why national political cultures are interesting objects of research for scholars, even in our very globalized century. But nationalism has proved to be a double edge sword. At least since the beginning of the 20th century, the appeals to patriotism have legitimized some of the worst crimes recorded in world history. What is your personal evaluation of nationalism nowadays?

HR: I do see that the nation is still a powerful source of identification and aspiration. To do something within Germany seems to be so much more realistic that doing it within Europe. The bigger the context ("we should do something at the European level or on the global level"), the stronger the feeling of being powerless. I really think that this has to do with the desire of a collective shaping of the world, and it seems that national institutions are still the better way to do it. So, the nation is important, but I do think we need to find better solutions. Now you might remember the Erasmus program in Europe. If you look at students and young academics, they do develop something like a European identity, and a lot of them do care for Europe. But you do have this split between the "somewheres" and 
the "anywheres". As far as I am concerned, only an elite has European dreams, and the thing gets even more difficult at the global level. During most of modern history, the nation was the focal point of identity. You feel yourself as a French or as a German. My hope is that there will be a multi-layered system, in which you could affirm yourself as indigenous and Chilean and Latin-American and a citizen of the world at the same time. This implies that we do not need to dissolve the nation - it can remain a strong focal point, but not the exclusive one. And I am thinking now of a cultural multilayered reality, consolidated along an institutional multilevel system. I am stressing now the emotional side of the story - that I can feel myself part of my village in Baden Würtenberg, of Germany, of the EU, and also care for the United Nations.

DM: So, in terms of evaluation, you would say that the nation leads us into trouble when it remains the exclusive focus...

HR: ... that's right. And it is very frightening to see how the rhetoric has changed. You saw it in Britain and in the US, and now you see the same in Hungary or elsewhere. I would claim that, before Boris Johnson and Donald Trump, a politician would not have simply said "I do everything that is good for England" - he would always have added, "and for Europe and the world". Even if it was empty rhetoric. And I am not implying that before Trump the US was led by saints and heroes. Obama's foreign policy was terrible. But at least he would always create this sense of "let us build a great America for the benefit of the whole world" - and now Trump scratches the "for the benefit of the whole world" part. It is the same in England. Boris Johnson did not say "I'm sure Brexit will make England great and be a good thing for Europe". This is an incredible backlash obviously, and if we do not manage to correct it, we might go into the Third World War, that would probably be the final one.

DM: At least Emmanuelle Macron seems to have a convinced pro-Europe stance...

HR: Macron definitely, but not Merkel. Macron said one hundred times "we need a stronger Europe, but we also need a capacity to speak together in terms of foreign, military 
policy, we need a United Europe", while Merkel's discourse always implies the position of "no, I'm slaved to the United States". Just over the weekend, Macron made a last attempt in this direction, and Annegret Kramp-Karrenbauer, our [Germany] defense secretary, said something like "no, we don't want to go with the French because of our good friends and partners, the United States of America." The same with Heiko Maas, our foreign minister. They are total slaves! That is why I always said, "I almost hope Donald Trump will be reelected because this would force the Europeans to think by themselves". Now the Germans are all for the United States. Led by the US, they have invaded Iraq and other countries of the region, and killed more than 500,000 people. And they say they stand for human rights! This hypocrisy of the West is a horrible problem. So, just to be clear: the Germans blocked a stronger Europe. The so-called Coronabonds would have been such a good idea because we would have been in this together, but Merkel has remained skeptical towards issuing them.

DM: I would like to close by asking you to give an overall evaluation of your theory of modernity. I tend to think of modernity as a culturally-specific phenomenon, which emerged in Western Europe around the 15th century and then spread all around the world. You, on the other hand, have put forward an analytic framework for understanding modernity, complemented by an interpretation of underlying human self-understandings. But the core of the theory tends to have "acultural", universalistic claims. ${ }^{8}$ I would appreciate your thoughts on this.

HR: It is interesting that you bring this point, something that I think I have clarified in a book I am writing with the German sociologist Andreas Reckwitz-the author of the book Die Gesellschaft der Singularitäten. In this last piece of work, I give a complete account of modernity along these two sides. My claim now is that modernity is a "social formation" composed of a certain cultural outlook - a self-interpretation - and an institutional setting. On the institutional side, modernity is in my view a system of dynamic stabilization: a modern society is a society which can only stabilize dynamically, i.e., that structurally requires technological acceleration, economic growth, and cultural innovation to reproduce 
and maintain itself. However, on the cultural side, it is the first-person perspective: where do the desires and anxieties come from? The claim here is the "Triple A" horizon of the good life, that is, making the world attainable, available, accessible, or what I call in German Weltreichen vergrößerung. I think that this desire of increasing the horizon of what can be known is science's driving force - what can be controlled is what is driving technology; what can be possessed is what is driving the economy; what can be regulated is what is driving politics... And yet, it is always the same gesture, the same desire of increasing your reach over the world. But we are also driven by the fear of not having a legitimate place in the social order, of being left out. And thus, I provide an analysis of why things are going wrong. On the institutional framework it is desynchronization, while on the cultural side it is alienation. How could this be corrected institutionally? Socially, by adapted stabilization; and culturally, by resonance. My general claim is that culture provides the energy, the motivational energies, since an institution cannot speed up by itself; in the case of the modern social formation, this energy comes from the triple A horizon to the good life.

DM: Now, with the notion of "social acceleration" you put forward an analytic tool. In other words, you do not want to engage in a strong evaluation. Right?

HR: Yes, what I still say is the following: my definition of modernity does not have any normative implication; it is the system that needs to speed up to sustain itself - therefore, it is void of strong evaluation. Strong evaluations belong to the cultural side. What I call the cultural side, or the first-person perspective, refers to the "moral map" providing the energy. I am still thinking with Charles Taylor in that culture underlies the institutional framework, but you can also separate both. However, even my definition of Weltreichen vergrößerung or Verfügbarmachung is a kind of analytical concept. For me as a sociologist, it is an analytical concept, but for the culture of modernity is, of course, a strong evaluation.

DM: Yes, because these strong notions originated in Europe at a certain point in time. So, my question is: can you trace the genealogy of this modern social formation, including the cultural and institutional bits, to a particular place and time? 
HR: I agree with you in that it starts in Europe and then spreads out. And I would say that, in Europe, it begins with a cultural shift, with the Enlightenment and so on, and then it creates the institutional fabric. But if I think of China nowadays, I would say it happens the other way round: first importing or adapting modern science and legal institutions, and then developing the cultural set that comes with it.

DM: Sure, because they copy almost everything...

HR: I know, they are good at copying, and they are getting much better at it, but now I think they are at the point of creating something new. And is not the West incredibly hypocritic? The West did not only fight for free markets, but we also enforced them with brutal military force, as the Chinese know. Today, for the first time, the Chinese have put away a technology that can compete with Western technology. And what do we do? We block them politically. It is the most unfair thing you can possibly do. Look at the way how they overcame Covid19, they just do not have it anymore. I really believe these stories are not made up, or that the Chinese are lying on us. They are paying a heavy political price, but in China there seems to be no more Corona-problems. And yet in the West they are totally incapable of dealing with it.

DM: But that does not mean that the Chinese are very creative or original...

HR: They invented a vaccine and a way to deal with this virus. We did not.

DM: Ok, you are right, they are intelligent and workaholic, but I have not seen coming from China anything as original and influential as natural science or Western music, including rock and roll. We all live nowadays according to the Western ways, especially Anglosaxon ideas and practices. Don't you think?

HR: I always argue like that. I think it depends a bit on what they do over there. I have always said that it is our social formation, which might work even better in China. But I am 
not quite sure anymore. On the one hand, I am so furious about Western arrogance; in Germany everyone believes, firstly, that the Chinese cannot be half as good as we are; and secondly, that they are evil, that whatever they say implies chaos and violence. This is arrogance and stupidity at once. We would be much better off if we finally came to listen and answer, instead of dogmatically knowing. You talk to school children in Germany, and they would say "the Chinese are dictatorial, brutal and stupid", and I find this totally unacceptable. The fact that we do not know anything creative from China has partly to do with the fact that we totally ignore them because we think we know it much better anyway. On the other hand, when I was in China - and I was there twice - I must say that I found your perspective quite plausible. They admire Western cars, fashion, universities, and in this sense, it does not seem as if they were creating their own thing. So, I am undecided on this point.

DM: In any case, you raise an important point about the necessity of opening a fair conversation between the West and Chinese culture and ways of doing things. In Chile, as well, there prevails a general feeling of contempt towards the Chinese.

HR: And it has gotten much worse over the last two or three years. It is a global Western effort to stem the Chinese success. I really think we are going down the drain, and they are coming up. And this will almost certainly change the social formation, it will not stay there forever. I think they will take off from our social formation. What the result will be, I have no idea. 


\section{Bibliographical References}

Blumenberg, Hans. Lebenszeit und Weltzeit. Frankfurt am Main : Suhrkamp 2001

Gronemeyer, Marianne. Das Leben als Letzte Gelegenheit. Sicherheitsbedürfnisse und Zeitknappheit. Darmstadt: Wissenschaftliche Buchgesellschaft, 1993.

Rosa, Hartmut. Resonance: A Sociology of Our Relationship to the World. Cambridge: Polity Press, 2019.

------. Social Acceleration. A New Theory of Modernity. New York: Columbia University Press, 2013.

-----. Identität und kulturelle Praxis: Politische Philosophie nach Charles. Frankfurt am Main: Campus, 1998.

Taylor, Charles. "Two Theories of Modernity". Hastings Center Report 25, no. 2 (1995): 24-33.

Recibido: 20 de septiembre de 2020

Aceptado: 5 de noviembre de 2020

\section{About the authors}

Hartmut Rosa. Professor of General and Theoretical Sociology at the Friedrich Schiller Universität Jena (Jena, Germany). Director of the Max-Weber-Kolleg in Erfurt since 2013. Among his most important works are Resonance: A Sociology of Our Relationship to the World (Cambridge: Polity Press 2019); Social Acceleration. A New Theory of Modernity (New York: Columbia University Press, 2013); and Alienation and Acceleration. Towards a Critical Theory of Late-Modern Temporality (Malmö/Arhus: NSU Press, 2010). He received the Erich Fromm Prize in 2018. E-mail: hartmut.rosa@uni-jena.de.

Darío Montero. Assistant professor of the Department of Sociology at the Universidad de Chile (Santiago, Chile). Doctor of Sociology by the University of Jena, Germany; master of Public Policy by the Willy Brandt School of Public Policy at the University of Erfurt, 
Germany; and Sociologist with a minor in Philosophy by the Pontificia Universidad Católica de Chile. He teaches political philosophy and social theory. Research assistant at the Center of Social Conflict and Cohesion Studies COES from 2014 to 2018. Guest editor at journals Persona y Sociedad and Arte y Sociedad. His publications deal with democracy, political cultures, national identities. Currently, he is working on a large study on the rise of modern society. Co-author, with Mauro Basaure, of Investigación y teoría critica para la sociedad actual (Barcelona: Editorial Anthropos, 2018). E-mail: dario.montero@uchile.cl. 